\title{
Developing Quality Culture in Power Plant Construction Company to Improve Competitiveness
}

\author{
Satya Nugraha, Yusuf Latief
}

\begin{abstract}
The tight competition in the construction sector in Indonesia's infrastructure projects presents a challenge to construction service companies, especially in the power plant infrastructure industry. To improve the competitiveness of construction service companies, customer satisfaction guarantees must be created, as follows: 1) Products must be in accordance with the requirements, the project done is completed on time, the costs incurred are relatively cheap and collateral for Health, Safety and Environment (HSE) should be realized. In creating customer satisfaction, the concept of Quality Culture needs to be applied. By using the Deming Cycle method in building a quality culture, it is expected that power plant construction service companies could increase competitiveness. This study aims to determine the effect of developing a quality culture on power plant construction service companies, data obtained through archival analysis, interviews and questionnaire surveys. Data processing concludes the activities needed on developing a quality culture for risk-based organizational functions in power plant construction service companies as a way to increase competitiveness. The results of this study are the concept of building a PDCA-based quality culture in the Quality Management System in a power plant construction services company.
\end{abstract}

Keywords: Competitiveness, Construction Service Company, Quality Culture, Power Plant

\section{INTRODUCTION}

National electricity demand is expected to be met with electricity infrastructure development carried out by the Government, Regional Government and PT. PLN (Persero). To meet these electricity needs, the Indonesian government opens opportunities to all parties that have been regulated in UU No.30 year 2009 about Electricity and UU No.3 year 2009 about Financial Balance between Central and Regional Governments.

Based on UU No 30 year 2009, the businessman of the Public Interest Electricity Supply Business (PIUPL) consists of:

First is Government and regional governments through BUMN (national) and BUMD (regional) carry out Electricity Supply Business for Public Interest. And second one is Private business entities, cooperatives, and nongovernmental organizations can participate in the Electricity Supply Business for Public Interest.

Revised Manuscript Received on April 19, 2019.

Satya Nugraha, Magister Student of Engineering in Civil Engineering,

Yusuf Latief, Professor of Department of Civil Engineering, University of Indonesia. University of Indonesia.

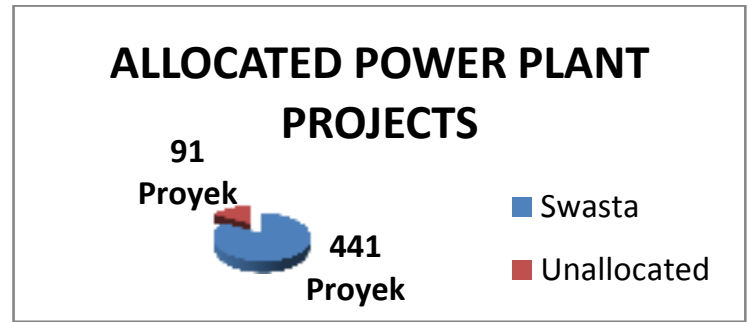

Source: General Plan for Electricity Supply (RUPTL) PT. PLN 2017-2021

Based on the Regulation of the Minister of Industry of the Republic of Indonesia Number: 04/M-IND/PER/1/2009, concerning Guidelines for the Use of Domestic Production for Electricity Infrastructure Development, that the Government expects the role of Foreign Components (KLN) with Domestic Components (KDN) can work together in realizing Electricity Infrastructure Development. From the results of the analysis, it is found that the role of domestic components for Integrated Construction Services (EPC) for PLTU, PLTP and PLTA projects still requires foreign components. This considers the quality that supports the construction of electricity infrastructure and grows the industry and increases the competitiveness of domestic components to support the independence of national electricity infrastructure development.

\section{KDN \& KLN for Construction Services...}

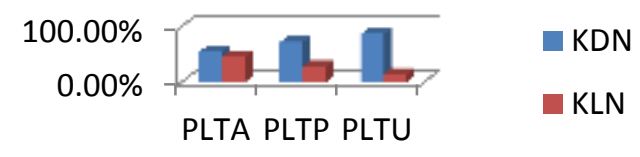

Source: Regulation of the Minister of Industry of the Republic of Indonesia

Number: 04/MIND/PER/1/2009

To support the independence of national electricity infrastructure development, it is necessary to improve the competitiveness of national construction services companies. Definition of Competitiveness is the level of productivity which is interpreted as output produced by a workforce (Porter, 1990). Whereas the definition of Company Competitiveness is the ability of a company to create and formulate a variety of strategies that can place it in a strategic position and more profitable compared to other

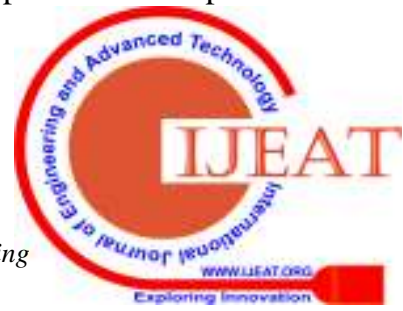


companies (Tangkilisan, 2003). According to (Goetsch, 2014), quality is defined as a dynamic condition connected to products, procedures, setting, services, and individuals that satisfy customer desires and needs and assists in generating higher value. Problems that occur in the construction process have the possibility of Rejection, Repair, and Replaced for the progress of project. Problems can occur for work areas that are in contact with the existing plant area (Brown Field) or areas that are really new land (Green Field). Some examples of phenomena and issues that commonly occur in the world of power plant construction divided in 3 stages of process, such as:

\subsection{Planning Process}

Every important Drawing should be officially transmitted, before used for construction process. DED (Detail Engineering Drawing) needs to be submitted by a consultant to the contractors officially, but sometimes when the drawing needs to be revised, the drawing are not officially back transmitted. It is possible to have false referenced drawing on field.

Some issues occurred on the scheduling and material budget planning. It is possible to have problems when the specification materials are changing between before and after planning process. The same problems also occurred on the human resource planning. The word "quality" has different understanding on everyone, especially in their own specific ways; however, everybody can realize what is referred to as 'quality' (Chandrupatla, 2009).

\subsection{Constructing Process}

The construction is one industry being viewed with poor quality compared to other sectors, such as: Manufacturing and Service sectors (Kubal, 1994) ; (Kanji, 1998) ; (Love, 2000). The cultural and behavioral shift in the construction process is needed to improve performance (Haupt, 2004).

(Rowlinson, 1995) point out that the construction industry is also characterized by its non-standardization. Production processes are to some extent different from one another. Hence, no universal standard or specification can be applied to the product, which leads to difficulties in quality assurance. Furthermore there are excessive changes to the details of the design of a project are typical throughout the construction process. They may be attributed to the lack of buildability of the design produced or variations by the contractors for the sake of speed and cost of production . Quality is often at risk because of the excessive changes (Kanji and Wong, 1998).

\subsection{Evaluation Process}

Many companies have difficulties in implementing Quality Management. It may happened when there are lack of consistent senior management commitment and support and style of manager's leadership, lack of a formalized strategic plan and also conflicting priorities. There is also a lack of work discipline, resources and support, financial crisis, an organizational approach, a long-term focus and failure in understanding the voice of the customer will then affect corporate culture and cause problems (Mosadeghrad, 2006)

\section{LITERATURE REVIEW}

\subsection{Quality Culture}

Quality has a three-fold meaning (Hart, 1994). In the context of construction, it means getting the job done on time; ensuring that the basic characteristics of the final project fall within the required specifications; getting the job done within budget. In the twentieth century, Quality is an approved management concept and it is driving organizational competitiveness and effectiveness (Wan Yusoff bin Wan Mahmood, 2008). Quality Culture includes the coordination of shared principles and standards that is concern on delighting customers and constantly enhancing the quality of products and services (Malhi,2013). In an organization, quality is deeply rooted in almost every facet of organizational life. The culture of an organization could be considered as the business source attitude and value. It is this culture that defines guidelines, techniques and activities within an organization (Batten, 1994).

The application of TQM is influenced by Organizational, Vocational and National Culture, and organizational culture is the most influential of the others. Organizational culture identifies 13 dimensions of quality culture, including: Leadership, Customer Focus, Teamwork, Involvement, Empowerment, Communication, Education \& Training, Continuous improvement, Motivation, Supplier partnership, Organization structure, Recognition \& Reward, \& Strategy and quality Policy (Wan Yusoff bin Wan Mahmood, 2008). Critical factors Total Quality Culture are Leadership and Empowerment. And it was stated that this affected any organization that wanted to develop Total Quality Culture. Information and Communication is not the dominant factor that must be developed in Total Quality Culture. (Ana Cláudia Campos, 2014). In implementing a Quality Culture, activities that support Total Quality Management are needed. Every change that needs to be done, refers to the influence of quality culture factors (Adebanjo, 1999). In order for a successful TQM program to be carried out as follows: collaborative and corporate organizational culture supported by management and employees, continuous commitment and involvement, organizational learning, innovation and entrepreneurship, team work and collaboration, open communication, risk taking, continuous improvement, customer focus (internal and external), partnerships with suppliers, and quality monitoring and evaluation must be developed. It was established as guidelines for implementation, strategies and processes must be aligned. and integrated in quality culture, and information systems must be integrated (Mosadeghrad, 2006). TQM embraces the philosophy, principles, procedures and practices needed to provide customer satisfaction and achieve business productivity and performance in the construction industry. Commitment and perseverance is needed when starting the application of TQM (Low SuiPheng, 2004).

Organizational culture and national culture are important factors in implementing TQM. The construction industry is 
based on a culture that encourages the giving of projects to the lowest bidder. For this reason, clients adopt a very narrow view of relationships with designers and contractors.
Namely they choose contractors based on price and expect their interests to be protected through contractual provisions (Ngowi, 2000)

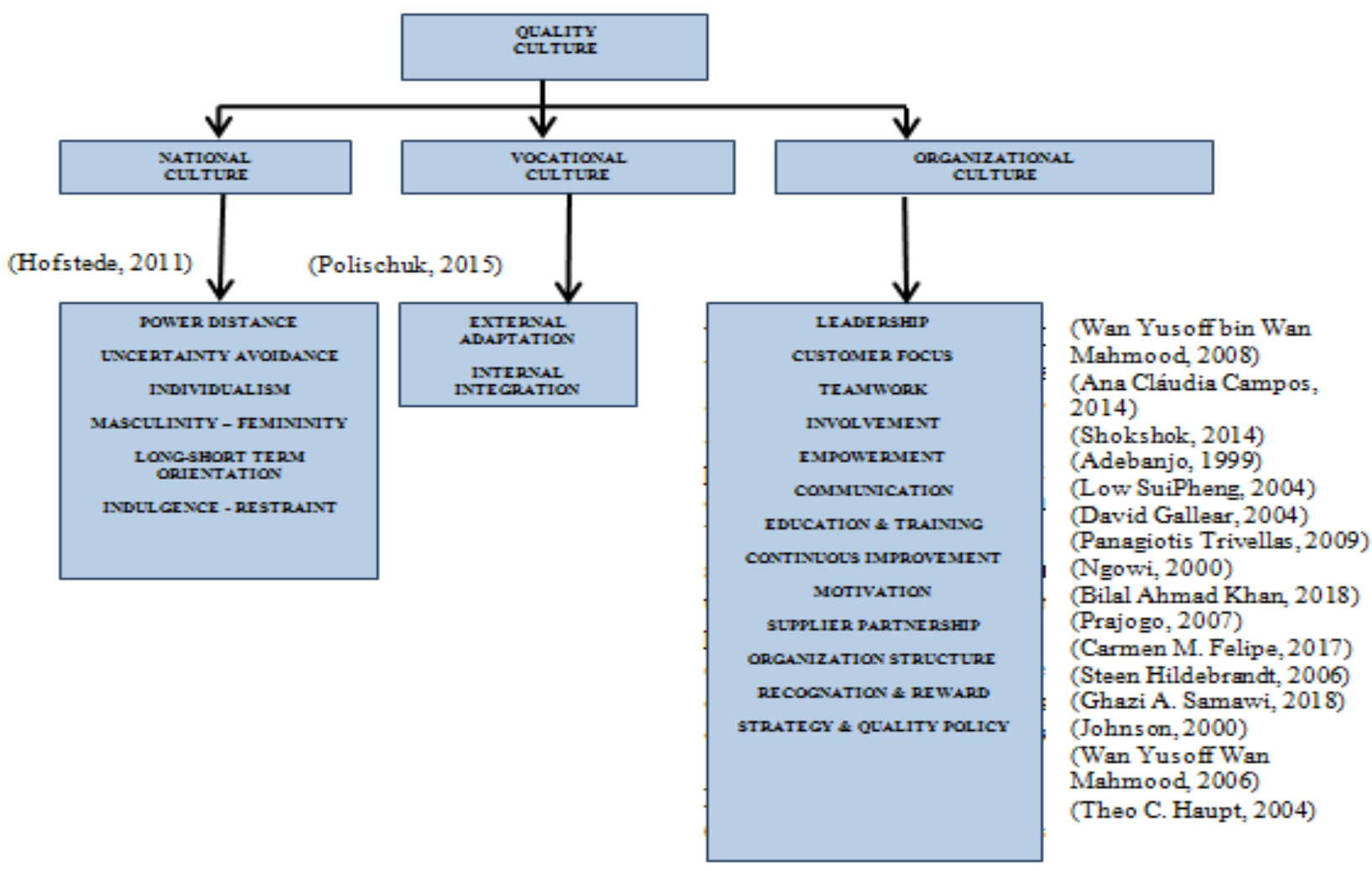

Figure 1. Variable Construct of Developing Quality Culture

\section{Power Distance}

Power Distance has been defined as the extent to which members who are less powerful organizations and institutions (such as families) accept and expect power to be distributed unevenly. This represents inequality (more versus less), but is defined from below, not from above. This shows that the level of community inequality is supported by many followers as practiced by leaders. Power and inequality, of course, are very basic facts of society. All societies are not the same, but some are more unequal than others

\section{Uncertainty Avoidance}

Uncertainty avoidance is not the same as risk avoidance; this is related to community tolerance of ambiguity. This shows the extent to which a culture programs its members to feel either uncomfortable or comfortable in unstructured situations. Unstructured situations are novels, unknown, surprising, and different from usual. The culture of uncertainty avoidance tries to minimize the possibility of situations such as strict codes of conduct, laws and rules, rejection of deviant opinions, and beliefs in absolute Truth; 'There is only one Truth and we have it'

\section{Individualism}

On the individualist side we find a culture where ties between individuals are loose: everyone is expected to care for themselves and their close family. On the collectivist side we find a culture where people from birth onwards are integrated into groups that are strong, cohesive, often large families (with uncles, aunts, and grandparents) who continue to protect them in exchange for unquestioned loyalty and opposition another group. Again, the problem handled by this dimension is very basic, about all the people in the world

\section{Masculinity - Femininity}

It is not the gender influences the culture, but the commitment to create the best performance with the big effort

\section{Long-Short Term Orientation}

This dimension is highly correlated with recent economic growth. Because none of the four IBM dimensions are related to growth economics, I obtained Bond permission to add dimensions as fifth for my four (Hofstede, 2011).

\section{Indulgence - Restraints}

It's about self-control to immediately find out the results

\section{Vocational Culture}

Vocational is the ability to explore the problems of education and work, assessment of self-abilities associated with work problems, planning work problems, making decisions in the selection of jobs. Vocational culture in the 
perception of quality culture is the provision of work ethics (work culture) in the process of part of learning competencies in the vocational sector.

\section{Internal Integration}

This is an ability to generate all function at the office then create the efficient of business process within the integration framework.

\section{External Adaptation}

It is the skill to understand how to keep on standing in bad situation or to make the better condition in the business process or performances.

\section{Leadership}

The timeline of organizational culture also includes two other important elements of strategy for business competitiveness: cost optimization and orientation towards product manufacturing or the provision of services with high added value. This business strategy focus is known as 'leadership costs' and 'differentiation

\section{Costumer Focus}

The requirement for restructuring in an organization is to meet customer satisfaction. In construction, known 3 customer satisfactions, including: Work Safety, Quality achieved, Cost efficient, Time in accordance with planning.

\section{Team Work}

Teamwork is a form of group work that aims to achieve targets that have been agreed upon previously. It must be realized that teamwork is a variety of personal fusion that becomes a person to achieve a common goal. The goal is not a personal goal, not a team leader goal, nor is it the most popular personal goal in the team.

Understanding and supporting each other is the key to success from teamwork. Never ignore this understanding and support. Even though personal disputes occur, the team must immediately get rid of them first. If not, life in the team will obviously be disrupted. Even in one team it may come from a different division background which sometimes also stores disputes. So it's very important to realize that togetherness as a team member is above all.

\section{Involvement}

Job involvement as the level to what extent a person's work performance influences his self-esteem and the degree to which someone psychologically identifies himself with his work or the importance of work in his total self-image. Individuals who have high involvement more identify themselves at work and consider work as a very important thing in their lives.

\section{Empowerment}

The empowerment model including:

\section{Desire}

The first step in the empowerment model is the desire of management to delegate and involve workers. These include: Workers are given the opportunity to identify developing problems. Minimize directive personality and expand worker involvement. Encourage the creation of new perspectives and rethink work strategies. Describes team expertise and trains employees to master themselves (selfcontrol

Trust

After the desire of management to empower, the next step is to build trust between management and employees. The existence of mutual trust between members of the organization will create good conditions for the exchange of information and advice without fear. Things that are included in the trust include: Providing opportunities for employees to participate in policy making. Providing sufficient time and resources for employees to complete work. Providing adequate training for work needs. Appreciate differences in views and appreciate the success achieved by employees. Providing sufficient information access.

\section{Confident}

The next step after mutual trust is to create employee confidence by respecting the capabilities possessed by employees. Things that include actions that can cause confidence include: Delegating important tasks to employees. Explore ideas and suggestions from employees. Expand tasks and build networks between departments. Provide a job instruction schedule and encourage good solutions.

\section{Credibility}

The fourth step is to maintain credibility by rewarding and developing a work environment that encourages healthy competition so as to create organizations that have high performance. Things that include credibility include: Viewing employees as strategic partners, increasing targets in all parts of the work, Introducing individual initiatives to make changes through participation, helping to resolve differences in goal setting and priorities.

\section{Accountability}

The next step in the empowerment process is the employee's responsibility to the authority given. By setting consistently and clearly about the roles, standards and objectives of the assessment of employee performance, this stage is a means of evaluating the performance of employees in the completion and responsibility for the authority given. Accountability includes: Using training channels in evaluating employee performance, Providing clear tasks and clear measures, Engaging employees in determining standards and sizes, Providing advice and assistance to employees in completing workloads, Providing period and time of giving feedback

\section{Communication}

Communication is an important factor in many ways, including in fostering a quality culture. Organizations that have a good quality culture always have an effective communication model, both between individuals in groups and between groups. The flow of communication can be used freely, openly, honestly and lasts two directions, even a large company. 


\section{Education \& Training}

Training is very important for organizational employees to be more productive. Besides that Supervisors must be responsible for implementing a quality culture in their department, including teaching basic philosophy of quality culture to all their subordinates. Training that is usually needed by employees in supporting the implementation of a quality culture includes; interpersonal skills, teamwork skills, problem solving, decision making, analysis and improvement of work management performance, business economics, and technical skills. At the time of creation and formation of a quality culture, employees should be trained immediately so that they can become effective employees for the company.

\section{Continuous Improvement}

The process of improving quality is a fundamental need in the world of industry, banking, services, and education. His strategic position made Harrington dare to say, "Improvement is not part of the game - it is the game today. Everyone wants things to change for the better. ....... You can no longer wait for someone else to change. The improvement process must start with you ". The process cannot run once in a lifetime, but continuous or continuous efforts are needed.

\section{Motivation}

In principle, every individual involved in it will jointly strive to create ideal working conditions in order to create an atmosphere that supports the efforts to achieve the expected goals.

\section{Supplier Relationship}

Companies and Suppliers (Suppliers / Vendors) are in need of each other. Having mutually beneficial cooperation will enhance the ability of both parties to create value for success. Establish a balanced relationship between shortterm benefits with long-term consideration. Synergize expertise and resources in pairs with suppliers. Identify and select key suppliers. Arrange joint development, for flexibility and speed to respond to changing market needs. Give enthusiasm, encouragement and appreciation for the improvement and achievement of suppliers.

\section{Organization Structure}

Organizing is regulating the elements of agency / department resources that consist of labor, experts, materials, funds, etc. in a rare movement that is synchronous to achieve organizational goals effectively and efficiently. In the organization compiled and laid down the basics of guidelines and instructions for activities, reporting lines, division of tasks, and responsibilities of each group and leadership. Because the purpose of an agency / department is different, the organizational structure is also the same, meaning that no organization can be used for all kinds of activities and situations with the same results.

\section{Recognition \& Reward}

Performance is the result of work produced by employees or real behavior that is displayed in accordance with its role in the organization. Employee performance is a very important thing in the organization to achieve its objectives, so that various activities must be carried out by the organization to improve it.

\section{Strategy \& Quality Policy}

Quality strategy and policy is a form of company commitment to the quality of products produced in a business process, namely in the form of a quality management system. The Quality Management System defines how organizations consistently implement quality management practices to meet customer and market needs.

\section{Improving Competitiveness}

Improved good governance in the development of construction services seems to be the main key to competitiveness. Transparency in the provision of consulting services still needs to be improved. A suitable electronic procurement system must be made in selecting a consulting company (Rizal Z. Tamin, 2015). The TQM aspect is most important for increasing competitive advantage, thereby helping decision making about resource allocation (Sin Kit Ying, 2018).

The relationship between culture and economic growth is by no means a new subject (Gershman, 2016). There is a strong relationship between quality, strategy and competitiveness (Prajogo, 2007). Culture comprises of the convictions, standards and fundamental assumptions that support behavioral items and patterns (Ott, 1989) (Zeitz, 1997). Business strategy and communication relations are the dominant approaches carried out to improve competitiveness (Sauka, 2014). By using the Dynamic System it is known that the Time and Finance variables can be used as the dominant factor to determine the Competitiveness Index in the Construction sector (Dangerfield, 2010). It was concluded that awareness of the ownership of QMS ISO 9001 on a large scale qualifying contractor has utilized Indonesian construction companies to promote quality in carrying out construction projects and delivery of construction products. By showing that the importance of meeting quality construction products for the satisfaction of the project team, project owners, and project end users (Willar, 2017). The Porter's framework also helps detect problem areas for the industry and has provided valuable insights into possible solutions to be taken (ÖZ, 2001). The national construction industry in the future can grow fast and passionate if the right policies are set and consistently implemented according to their priorities (Hari G. Soeparto, 2014) 
International Conference on Recents Advancements in Engineering and Technology (ICRAET-18) |15th and 16th March 2019|Siddhartha Institute of Technology \& Sciences, Telangana, India.

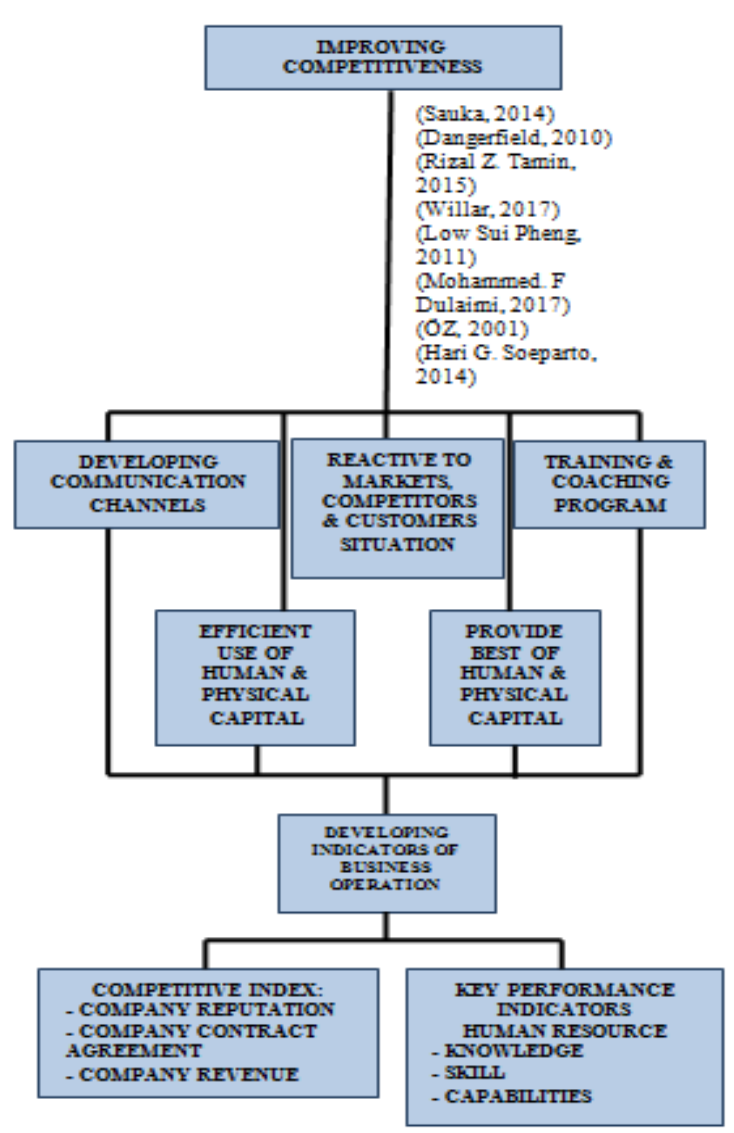

Figure 2. Variable Construct of Improving Competitiveness

\section{METHODOLOGY/MATERIALS}

This research performs study case at Power Plant Construction Service Company. The study is benchmarking to existing literature related to quality culture. Data obtained through literature analysis, and validated by experts. Questionnaire is validated by Structural Equation Models and strategy is benchmarking to Power Plant Construction Company. Modelling strategy to improve quality culture will be provided as the result.

\section{RESULTS AND FINDINGS}

After processed with SmartPLS, Crossloading analyses will be use to understand the dominant variable $\mathrm{X}$ improving variable Y. Please see the diagram below:

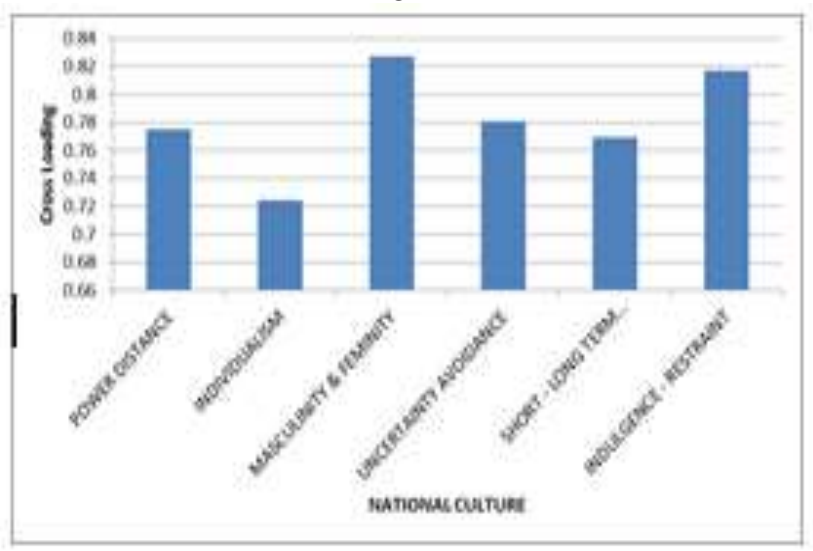

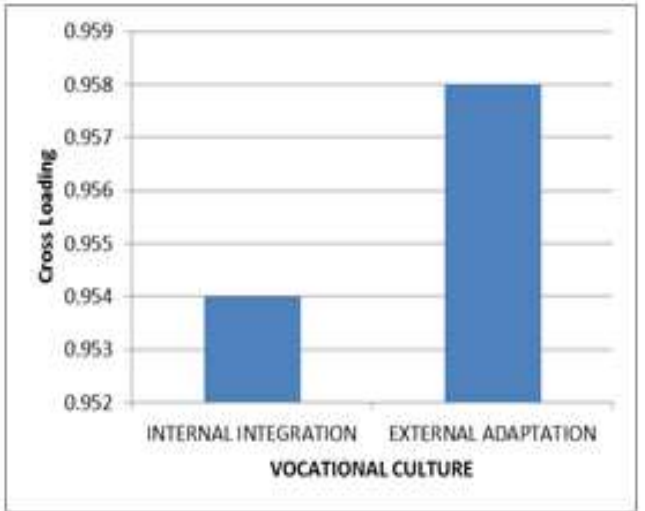

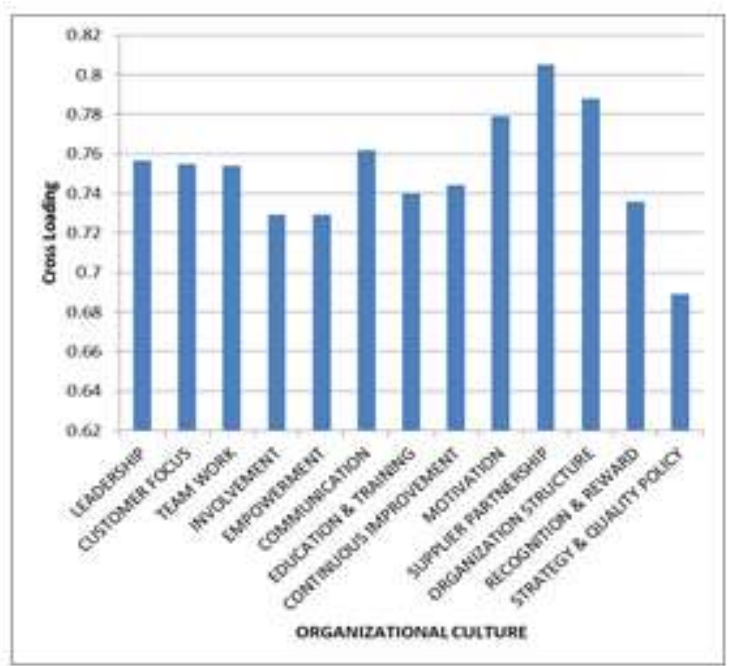

\begin{tabular}{|c|c|}
\hline $\begin{array}{c}\text { X Variable -----> Y } \\
\text { Variable }\end{array}$ & $\begin{array}{c}\text { T Statistics } \\
(|\mathbf{O} / \mathbf{S T E R R}|)\end{array}$ \\
\hline $\begin{array}{c}\text { National Culture ---- } \\
\text { > Competitiveness }\end{array}$ & $\mathbf{2 . 0 9 6}$ \\
\hline $\begin{array}{c}\text { Vocational Culture -- } \\
\text {---> Competitiveness }\end{array}$ & $\mathbf{3 . 9 5 7}$ \\
\hline $\begin{array}{c}\text { Organizational } \\
\text { Culture ----> } \\
\text { Competitiveness }\end{array}$ & $\mathbf{3 . 8 5 6}$ \\
\hline
\end{tabular}

There are 13 indicators of competitiveness that have cross loading values above the average, so it is stated that the dominant quality targets used as competitiveness in power plant construction service companies through a quality culture built on activities in their companies include:

1. PROJECT PERFORMANCE RECORD

2. ABILITY TO FORECAST MARKET CHANGES

3. RELATIONSHIP WITH CLIENTS AND CONSULTANTS

4. FINANCIAL STATUS

5. CREDIBILITY GRADE

6. PAYMENT TO SUBCONTRACTORS OR SUPPLIERS

7. LOAN REPAYMENT

8. QUALITY CONTROL 


\section{COORDINATION WITH SUBCONTRACTORS \\ 10. ENVIRONTMENTAL \& SAFETY MANAGEMENT \\ 11. KNOWLEDGE CONSTRUCTION LAW \\ 12. ORGANIZATIONAL STRUCTURE \& CULTURE \\ 13. QUALITY OF PERSONEL}

\section{CONCLUSION}

Quality Culture in Power plant construction companies for improving competitiveness.

The purpose of this study is to develop quality culture in power plant construction companies. By developing of national culture, vocational culture and the most important thing is organizational culture, company could understand their performance and build strategies for their future business development. Quality culture is expected for integrating project management. In a conventional company, the construction process has no standard quality of management. As time goes by, Companies are interested in quality management standards because it facilitates their work processes. Unfortunately, the standard could not guarantee that their company's competitiveness will be improved. Only one could guarantee quality management, it is Quality culture.

\section{REFERENCES}

1. Adebanjo, D. (1999). An investigation of quality culture development in UK industry. International Journal of Operations \& Production Management, Vol. 19 No.7, 633-649.

2. Ana Cláudia Campos, J. d. C. M., João Albino Silva, Patrícia Oom do Valle. (2014). Critical success factors for a total quality culture: A structural model. Tourism \& Management Studies, 10(1).

3. Batten, J. (1994). A total quality culture. Management Review. Vol.94, 61.

4. 4. Bilal Ahmad Khan, H. N. (2018). The impact of strategic quality orientation on innovation capabilities and sustainable business growth. International Journal of Quality \& Reliability Management, Vol. 35 No. 8, pp. 1568-1598. doi: 10.1108/IJQRM-07-2017-0126

5. Carmen M. Felipe, J. L. R. a. A. L. L.-R. (2017). Impact of Organizational Culture Values on Organizational Agility. Sustainability. doi: 10.3390/su9122354

6. Chandrupatla, T. R. (2009). Quality and reliability in engineering. Cambridge: Cambridge University Press.

7. Dangerfield, B., Green, SD and Austin, S. (2010). Understanding construction competitiveness : the contrib ution of system dynamics. Construction Innovation, Vol. 10(4), pp.408-420. doi: 10.1108/14714171011083579

8. David Gallear, A. G. (2004). An Empirical Investigation of the Channels that Facilitate a Total Quality Culture. Total Quality Management \& Business Excellence, Vol.15(8), 1043-1067.

9. Dilek Cetindamar, H. K. (2013). Measuring the competitiveness of a firm for an award system. Competitiveness Review: An International Business Journal, Vol.23(1), 7-22. doi: $10.1108 / 10595421311296597$

10. Dragana Velimirovića, M. V. a. R. S. (2011). ROLE AND IMPORTANCE OF KEY PERFORMANCE INDICATORS MEASUREMENT. serbian Journal of Management, 6(1), 63-72.
11. Gershman, B. (2016). Long-Run Development and the New Cultural Economics. SSRN Electronic Journal, 221-261. doi: 10.2139/ssrn.2834628

12. Ghazi A. Samawi, e. a. (2018). Relation between Total Quality Management Practices and Business Excellence: Evidence from Private Service Firms in Jordan. International Review of Management and Marketing, 8(1), 28-35.

13. Goetsch, D. L., \& Davis, S. B. (2014). Quality management for organizational excellence. Upper Saddle River, NJ: Pearson.

14. Hari G. Soeparto, B. T. (2014). Industri Konstruksi Indonesia: Masa Depan dan Tantangannya. ITB Journal.

15. Hart. (1994). Quality Handbook for the Architectural, Engineering and Construction Community. Milwaukee: ASQC Quality Press.

16. Haupt, T. C., and Whiteman, D. E. (2004). Inhibiting factors of implementing total quality management on construction sites. The TQM Magazine, vol. 16, No. 3, pp. 166-173.

17. Hofstede, G. (2011). Dimensionalizing Cultures: The Hofstede Model in Context. Online Readings in Psychology and Culture, 2(1). doi: 10.9707/23070919.1014

18. Johnson, J. J. (2000). Differences in Supervisor and NonSupervisor Perceptions of Quality Culture and Organizational Climate. Public Personnel Management Vo. 29 No.1.

19. Kanji, G. W., A. (1998). Business Excellence model for suppl y chain management, Total Quality Management. vol. 10(no. 8), pp. 1147-1168.

20. Kubal, M. (1994). Engineered quality in construction : partnering and TQM. (McGraw-Hill, New York).

21. Love, P. E. D. a. H., L. (2000). Total quality $\mathrm{m}$ anagement and the learning organization: a dialogue for change in construction. Construction Management and Economics, Vol. 18 No. 3 pp. 321-331.

22. Low Sui Pheng, G. S. (2011). The Application of the Just-in-Time Philosophy in the Chinese Construction Industry. Journal of Construction in Developing Countries, Vol. 16(1), 91-111.

23. Low SuiPheng, J. A. T. (2004). Implementing Total Quality Management in Construction Firms. JOURNAL OF MANAGEMENT IN ENGINEERING. doi: 10.1061/ ASCE! 0742-597X 2004!20:1 8!

24. Michael L Smith, J. E. (2015). Role \& Responsibility Charting (RACI).

25. Mohammed. F Dulaimi, e. a. (2017). Building a World Class Construction Industry In Singapore. CIB World Building Congress.

26. Mosadeghrad, A. M. (2006). The impact of organizational culture on the successful implementation of total quality management. Article in The TQM Magazine, Vol. 18 No. 6(Tehran University of Medical Sciences). doi: 10.1108/09544780610707101

27. Ngowi, A. B. (2000). Impact of culture on the application of TQM in the construction industry in Botswana. International Journal of Quality \& Reliability Management, Vol. 17 No. 4/5, pp. 442-452.

28. Ott, S. J. (1989). The organizational culture perspective. Florence(KY: Brooks/Cole).

29. ÖZ, Ö. (2001). Sources of competitive advantage of Turkish construction companies in international markets. Construction Management and Economics. doi: 10.1080/01446190010009988

30. Panagiotis Trivellas, D. D. (2009). Organisational culture, job satisfaction and higher education service 
quality: The case of Technological Educational Institute of Larissa. TQM Journal, Vol.21 No.4, 382-399. doi: $10.1108 / 17542730910965083$

31. Polischuk, T. P. (2015). Organizational Culture of Vocational and Technical Educational Institution: Concept, Content, Functions and Features. State Educational Establishment, 6(2), 112-116.

32. Porter, M. (1990). The competitive advantage of nations. Free Press.

33. Prajogo, D. I. (2007). The relationship between competitive strategies and product quality. Industrial Management \& Data Systems, Vol. 107(Issue: 1), pp.6983. doi: $10.1108 / 02635570710719061$

34. Rizal Z. Tamin, e. a. (2015). Improving Indonesian Construction Consulting Services. ITB Journal. doi: 10.5614/j.eng.technol.sci.2015.47.2.8

35. Rowlinson, S. M. W., A. (1995). The Construction Industry in Hong Kong.

36. Sauka, A. (2014). Measuring the competitiveness of Latvian companies. Baltic Journal of Economics, Vol. 14(Nos. 1-2), 140-158. doi: 10.1080/1406099X.2014.995421

37. Shokshok, M. A. (2014). Quality Culture Framework Proposal for Libyan Industrial Companies. International Journal of Industrial and Manufacturing Engineering, Vol:8 No:7.

38. Sin Kit Ying, e. a. (2018). THE IMPACT OF TOTAL QUALITY MANAGEMENT (TQM) ON COMPETITIVE ADVANTAGE: A CONCEPTUAL MIXED METHOD STUDY IN THE MALAYSIA LUXURY HOTEL INDUSTRIES. Academy of Strategic Management Journal, Vol. 17(2).

39. Steen Hildebrandt, e. a. (2006). Quality culture and TQM. TOTAL QUALITY MANAGEMENT, Vol.2 No.1.

40. Tangkilisan. (2003). Kebijakan Publik yang Membumi, Konsep, Strategi dan Kasus. Lukman Offset dan YPAPI.

41. Theo C. Haupt, D. E. W. (2004). Inhibiting factors of implementing total quality management on construction sites. The TQM Magazine, Vol.16 Number.3(pp.166173). doi: 10.1108/09544780410532891

42. Wan Yusoff bin Wan Mahmood, A. H. b. M. (2008). A Conceptual Framework For The Deveopment of Quality Culture in The Construction Industry. Association of Researchers in Construction Management, 10.

43. Wan Yusoff Wan Mahmood, e. a. (2006). Development of Quality Culture in the Construction Industry. ICCI.

44. Willar, D. (2017). Developing attributes for evaluating construction projectbased performance. The TQM Journal, Vo.29(No.2), pp. 369-384. doi: I 10.1108/TQM04-2016-0036

45. Zeitz, e. a. (1997). An employee survey measuring TQM practices and culture: Development and validation. Group and Organization Management, 22(4), 414-444.

\section{AUTHOR PROFILE}

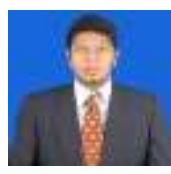

Satya Nugraha Obtained his bachelor's degree at Institute Teknologi Bandung, Major Geodetic \& Geomatics Engineering. At this moment, $\mathrm{He}$ is a post graduate student of project management at Universitas Indonesia. Since $2008 \mathrm{He}$ has a lot of experiences for Power Plant Construction implementation in Coal Mining Business operation and

Yusuf Latief He was born in Jakarta, March 7th, 1960. He obtained his bachelor, master and doctoral of Civil Engineering degree from Universitas Indonesia. Now, as a Professor and also a fulltime senior lecturer in UniversitasIndonesia, $\mathrm{He}$ has a lot of national and international journal especially for knowledge management in Project \& Construction Management. 